\title{
Effect of a Life Model to Alleviate Life Stressors Facing Divorced Women
}

Salwa Abdullah Abdul-Jawad (PhD)

Department of Social Work Fields The High Institute of Social Work in Alexandria 


\title{
Effect of a Life Model to Alleviate Life Stressors Facing Divorced Women
}

\author{
Salwa Abdullah Abdul-Jawad (PhD) \\ Department of Social Work Fields \\ The High Institute of Social Work in Alexandria
}

\section{Abstract:}

The main aim of this research is to test the effect of a life model to alleviate life stressors facing divorced women through implementing a professional intervention program - from the perspective of the generalist social work profession - by the researcher. The program was implemented on a sample of divorced women. The scale of life stressors of divorced women was built and applied to women participating in the study by the researcher. The participants were selected from women whose endpoints measure was elevated to such stressors, their number came to 54 cases. Those cases were divided into two groups: one experimental group consisting of 27 women, and one control group consisting of another 27 women. The professional intervention program was applied to the experimental group during a period of four months. The results showed the diversity of divorced women's stressors including psychological, social and economic stressors. The results also showed that an intervention program through a life model can help divorced women to cope with these psychological, social, and economic stressors.

Key words: Divorce, Life Model, Social Work, Professional Intervention, Stressors.

\section{Introduction}

Divorce may leave a woman feeling hurt, lonely and unhappy. Even if it was her choice to end the marriage, she may bear the scars of the broken relationship for a long time. Women normally suffer the most after a divorce, both in terms of quality of life and emotional well-being. Women may also suffer financially after divorce, particularly if she is the primary caregiver to any children resulting from the marriage. Without her husband's salary, she will have less money to cover bills and household expenses (Smock P. J, Manning W. D. \& Gupta S., p.794). 
Divorced women reported significantly higher psychological distress levels than married women in the years following a divorce. The stresses of being in an unhappy marriage may simply be replaced by different worries, such as not being able to trust a man again, struggling to find her perfect partner or a fear of being rejected.

The damage varies from one society to another, and by the environment in which they live, and whether the divorced woman is a housewife or working woman, rich or poor, educated or illiterate. Damage also varies depending on a woman's social situation and circumstances.

Separation and divorce are common phenomena in society today, but still represent a major life stressor for the individuals involved, with potentially strong negative consequences for the mental and physical health of all members of the family (Kelly J. B. \& Emery R.E, 2003, p.352).

In recent decades, marriage rates have fallen and divorce rates have risen. The divorce rate worldwide has been increasing steadily ("Wikipedia Divorce", 2008). Divorce rates have increased considerably during recent years not only in developed countries but also in developing countries. It has often been overlooked but it has certainly changed the family structure due to its pervasive destructive effects on society.

In the context of Egyptian society in the last few decades, divorce has become a big and complex problem. Divorce rates have increased significantly, having clear multiple and profound effects on each member of the family, especially children, women and society as a whole.

Divorced individuals, compared to their married counterparts, have higher levels of psychological distress, substance abuse, and depression, as well as lower levels of overall health (Amato P. R, 2000; Hughes M. E \& Waite L. J, 2009). Divorce has not only psychological consequences but also economic and physical consequences for divorced women, affecting their role in the family and in society.

Generally, psychological reactions to divorce range from uncertainty, anger, grief and depression to anxiety and the feeling that a woman's life is getting out of control. Therefore, divorce has long 
been viewed as producing mainly negative outcomes that leave divorcees in a state of deprivation (Margit G., 2010, p.47).

According to Pirmordi et al (2016), divorced women are vulnerable to psychiatric problems, and there is a significant difference between normal and divorced women in terms of emotional self-regulation (p.159).

Divorce is generally viewed as a prominent cause of depression in adults (Tennant C.: 2002, p.173). Even if it was her choice to end the marriage, divorce can have important economic consequences, especially for women (DiPrete T. A \& McManus P. A, 2000, p.343; Uunk W. 1, 2004, p.251) Separation and divorce invariably involve financial changes and economic stress, and different residence arrangements require different financial costs. So Smyth I., (2004) reviewed the consequences of divorce for adults, and found a decrease in the income and standards of living for women (p.20).

Thus, divorce has been found to be clearly related to women needing to be in full-time work (Austen S., 2004, p.153). Most research and studies conclude that divorcees and their children fare worse according to several indicators of psychological, physical and socioeconomic well-being compared to those who have not experienced divorce (E. G.,Amato P. R, 2000, p.1269; Amato P. R., 2010, p.650; Garriga A. \& Härkönen J., 2009, p.1).

Findings of these effects range from heightened poverty levels (Callens M. \& Croux C. 2009, p.368) and lower educational performance of the children of divorced parents, to increased occurrence of psychological distress (Amato P. R and Keith B. 1991, p.26), as well as many physical health conditions (Amato P. R \& James S., 2010, p .2).

There are several research studies that focus on divorced women's issues and the effects divorce has on her life, including its relation to psychological, social and economic variables. These research studies have reached some negative conclusions about the impacts of divorce on women's lives. One of the studies showed that divorced women experienced more depression, stress, loneliness, anxiety and a higher level of anger compared to married women. It also found that there is a significant difference in emotional and social well-being for divorced women compared to married women (Nida 
Z.\& rukhasana K., 2014, p.31). Another study found that the rate of emotional intelligence in divorced women is less than in married women, owing to the general health of divorced women suffering from the negative effects of divorce through conditions such as anxiety, tensions, insomnia and depression (Golami A. \& Bashlide K., 2014, p.28).

While another study indicated that the impact of divorce on motherhood was mostly negative, because motherhood for divorced women is full of challenges and disadvantages (Yang L. L., 2008, p.220).

Divorce leads to negative consequences for men, but it is actually a more weakening process for women in comparison, as it brings problems and additional obligations. During and after the divorce process, the point of view of society, as well as that of the divorcees' family, can have an impact on the life decisions a divorced woman makes. It was observed that the negative approach of families and society towards divorced women, limits the relationships of women with their friends, relatives and wider support network; making the life of divorced women even harder (KÜÇÜKŞEN K., 2016, p.826).

This study is different from previous research studies because it aims to measure the effect of a professional intervention program by using a life model to alleviate life stressors facing divorced women. Also, the study discusses how divorced women can alleviate psychological, social and economic stressors through practicing the life model steps.

According to Urie B. (1986), the life model is a practice model in which all environments and systems affecting human development are taken into account (p.34). Also, Germain C. B \& Gitterman A. (1996) link the life model to the ecological perspective, through realizing the fit between individual needs and capacities and environmental qualities (p.26).

The life model can help professionals to understand clients' needs and problems. Also, the model can help clients to deal with life stresses and its consequences. Client needs and troubles are identified as arising from three interrelated problems of living: life transitions, 
environmental pressures, and maladaptive interpersonal processes (Gitterman A.\& Shulman L., 2005, p.382).

The main aims of implementing a life model in the professional intervention program are:

1- Alleviating life stressors by helping people draw on personal and environmental resources for effective coping.

2- Influencing the social and physical environmental forces to be responsive to the individual's needs.

3- Improving social relations networks and alleviating the negative stressors those lead to poor performance.

\section{Study Hypotheses:}

The main hypothesis: There is a statistically significant difference in the degree in the post-test on the scale of alleviating life stressors for divorced women, between the control group and the experimental group, in favor of the experimental group.

\section{Sub- hypotheses:}

- There is a statistically significant difference in the degree in the post-test on the scale of alleviating psychological stressors for divorced women, between the control group and the experimental group, in favor of the experimental group.

- There is a statistically significant difference in the degree in the post-test on the scale of alleviating social stressors for divorced women, between the control group and the experimental group, in favor of the experimental group.

- There is a statistically significant difference in the degree in the post-test on the scale of alleviating economic stressors for divorced women, between the control group and the experimental group, in favor of the experimental group.

\section{Participants and Scale:}

The type of this study is "experimental study". The experimental method uses two groups, "the experimental group and the control group". The study was applied to a group of divorced women who are clients of the Association of Women and Development (legal support center for women) in Montaza District, Alexandria. The association is an active NGO, which provides various services to all women, particularly divorced women, and is based in an area with many slums that have spread as a result of the divorce problem. 
The number of women attending the center has reached (94) divorced women and the research applied the scale of life stressors on divorced women to them. Divorced women in this research were selected from those whose endpoints measure was elevated to such stressors, their number came to 54 cases. Those cases were divided into two groups: one experimental group consisting of 27 women, and a control group consisting of another 27 women. The professional intervention program was applied to the experimental group during a period of four months in 2017.

The pre-measurement for the two groups (experimental and control) was applied first, and, after implementing the professional intervention program on the experimental group, the researcher carried out the post-measurement for the two groups.

Table (1) The pre and post measurement for the experimental and control groups in the study sample

\begin{tabular}{|c|c|c|c|c|c|c|c|c|}
\hline \multirow{3}{*}{ Scale Variables } & \multicolumn{4}{|c|}{ Before Intervention } & \multicolumn{4}{|c|}{ After Intervention } \\
\hline & \multicolumn{2}{|c|}{$\begin{array}{c}\text { Experimental } \\
\text { Group } \\
\end{array}$} & \multicolumn{2}{|c|}{$\begin{array}{l}\text { Control } \\
\text { Group } \\
\end{array}$} & \multicolumn{2}{|c|}{$\begin{array}{c}\text { Experimental } \\
\text { Group } \\
\end{array}$} & \multicolumn{2}{|c|}{\begin{tabular}{|c|} 
Control \\
Group
\end{tabular}} \\
\hline & Mean & S.D & Mean & S.D & Mean & S.D & Mean & S.D \\
\hline $\begin{array}{c}\text { Psychological } \\
\text { Stressors }\end{array}$ & 2.37 & 0.31 & 2.31 & 0.29 & 1.33 & 0.17 & 2.30 & 0.30 \\
\hline $\begin{array}{l}\text { Sociological } \\
\text { Stressors }\end{array}$ & 2.42 & 0.26 & 2.40 & 0.24 & 1.32 & 0.18 & 2.41 & 0.25 \\
\hline $\begin{array}{c}\text { Economic } \\
\text { Stressors }\end{array}$ & 2.31 & 0.38 & 2.33 & 0.39 & 1.58 & 0.27 & 2.35 & 0.38 \\
\hline Overall & 2.37 & 0.30 & 2.36 & 0.31 & 1.40 & 0.18 & 2.39 & 0.30 \\
\hline
\end{tabular}

\section{Intervention}

The professional intervention program was developed in light of life model principles, objectives and phases, and is linked to the aims of the current study.

(1) The objectives of the intervention program: The main objective of the intervention program can be determined as practicing use of a life model to alleviate the life stressors, which face divorced women (as compressor event). The main objective can be divided into the following sub-objectives: Helping divorced women face the psychological stressors from which they suffer after separation, helping divorced women face the social stressors from which they 
suffer after separation, helping divorced women face the economic stressors from which they suffer after separation.

\section{Phases of professional intervention:}

\section{First phase:}

1/ Preliminaries: the researcher prepared herself cognitively, through access to what has been written about the stressors and its sources and types. The spatial and human field was determined by the researcher. Finally, the life stressors for divorced women scale was prepared and tested for reliability and validity.

2/ Explore the stressors: the researcher applied the scale, determined the study cases and defined the acceptance of the respondents regarding the implementation of the professional intervention program. In addition, the researcher identified systems surrounding divorced women, which cause stressors.

3/ Contracting: the researcher held an oral contract with the participants in order to obtain their approval for the implementation of the professional intervention program. This required the researcher to explain the aims of the study, the program activities and its duration.

\section{Second phase: (continuous work / change)}

At this phase, the researcher applied the following professional activities:

1/ Therapeutic techniques to alleviate the stressors from which divorced women suffer.

2/ Therapeutic techniques with other systems associated with divorced women and their families, relatives, neighbors and social institutions as a resource to alleviate the stressors.

3/ Helping participants to understand and analyze the current circumstances and stressors, which they face, through discussion and clarification, encouragement, explanation, emotional ventilation and sympathy.

4/ Clarifying the circumstances surrounding the participants by helping them to accept the reality in which they live, and employing methods to deal with current stressors, through the revitalization of their abilities and potential, whilst developing their self-confidence to face their fears.

5/ Decreasing feelings of anxiety through psychological support, such as the professional relationship and emotional ventilation. 
Curbing anxiety, self-modifying modern structure, creating a positive vision instead of the negative that led to tension and anxiety.

6/ Helping participants to confront stressors through self-reflection, in order to understand the factors that led to the emergence of stressors, and therefore understanding what behaviors should be abandoned.

7/ Reducing the sense of isolation and loneliness by helping participants to adapt to present social conditions, integrate into new relationships, and find sources of support to alleviate the stressors imposed by the changes associated with divorce.

8/ Working on understanding the participants' new role towards their children by explaining some of the socialization techniques that help to achieve family-compatibility, so the family, after divorce, can achieve social adjustment and function successfully.

9/ facilitating access to existing services and resources at the legal support center for women in the Association of Women and Development, and working to activate those services and resources with the aim that they satisfy participants' needs.

The therapeutic techniques used in the intervention program: professional relationship, communication, emotional ventilation, clarification, explanation, consolidation, role play, persuasion, exploration, self-direction, glances, focus on the present and the future (more than the past).

The professional intervention strategies used in the program: (persuasion, family communication building, co-operation empowerment, emotional adjustment).

The professional roles used in the intervention program: (enabler, teacher, assistant, advocate, mentor, planner, facilitator).

The professional skills used in the intervention program: observation, communication, decision-making, problem solving learning, listening, estimating feelings.

The scale: the current study used the life stressors that face divorced women. The scale includes three dimensions:

1/ The first dimension: the psychological stressors that face divorced women. 
2/ The second dimension: the social stressors that face divorced women.

3/ The third dimension: the economic stressors that face divorced women.

The researcher selected basic dimensions for measurement, and determined the sentences or phrases associated with each dimension of the scale. Answers to the sentences or phrases of the scale are determined as follows: Agree $=3$ degrees, Almost Agree $=2$ degrees, and not agree $=1$ degree.

The numbers of measured sentences or phrases in the scale are (44), divided into three main dimensions, as follows:

- High level measurement $=44 \times 3=132$

- Medium level measurement $=44 \times 2=88$

- $\quad$ Lower level of the measurement $=44 \times 1=44$

\section{Reliability and validity of the scale:}

- Face validity: the researcher presented the scale to a group of judges or arbitrators (11 people) who are specialists in social work, and experts in family counseling. They examined the scale and expressed their opinions on suitable items and sentences for the scale that would contribute towards the aims of the study. The researcher made all the corrections, modifications and suggestions. The words that obtained the approval rate were adopted at $85 \%$.

- Validity of internal consistency: The main aim of doing this test is to show the correlation between every dimension of the scale and the whole degree of it. It can be calculated by having the correlation coefficients between the degree of each dimension of the scale and other dimensions. The following table illustrates this:

Table (2) The correlation coefficients between every phrase and the dimension to which it belongs

\begin{tabular}{|c|c|c|c|c|c|}
\hline \multicolumn{2}{|c|}{ Psychological Stressors } & \multicolumn{2}{|c|}{ Social Stressors } & \multicolumn{2}{|c|}{ Economic Stressors } \\
\hline $\begin{array}{l}\text { No. of } \\
\text { phrase }\end{array}$ & $\begin{array}{l}\text { The correlati } \\
\text { on coefficient }\end{array}$ & $\begin{array}{l}\text { No. of } \\
\text { phrase }\end{array}$ & \begin{tabular}{|c} 
The correla \\
tion \\
coefficient
\end{tabular} & $\begin{array}{l}\text { No. of } \\
\text { phrase }\end{array}$ & $\begin{array}{c}\text { The correlation } \\
\text { coefficient }\end{array}$ \\
\hline 1 & 0.64 & 1 & 0.87 & 1 & 0.77 \\
\hline 2 & 0.61 & 2 & 0.87 & 2 & 0.68 \\
\hline$\overline{3}$ & 0.77 & 3 & 0.75 & 3 & 0.64 \\
\hline
\end{tabular}




\begin{tabular}{|c|c|c|c|c|c|}
\hline 4 & 0.76 & 4 & 0.67 & 4 & 0.67 \\
\hline 5 & 0.58 & 5 & 0.69 & 5 & 0.58 \\
\hline 6 & 0.72 & 6 & 0.72 & 6 & 0.71 \\
\hline 7 & 0.78 & 7 & 0.95 & 7 & 0.68 \\
\hline 8 & 0.57 & 8 & 0.75 & 8 & 0.88 \\
\hline 9 & 0.65 & 9 & 0.82 & 9 & 0.63 \\
\hline 10 & 0.55 & 10 & 0.80 & 10 & 0.55 \\
\hline 11 & 0.87 & 11 & 0.87 & 11 & 0.66 \\
\hline 12 & 0.75 & 12 & 0.58 & 12 & 0.68 \\
\hline 13 & 0.67 & 13 & 0.71 & 13 & 0.66 \\
\hline 14 & 0.69 & 14 & 0.76 & 14 & 0.64 \\
\hline 15 & 0.72 & 15 & 0.80 & & \\
\hline $\begin{array}{l}\text { Coefficient } \\
\text { of the } \\
\text { psychologica } \\
\text { I dimension }\end{array}$ & 0.862 & \begin{tabular}{|} 
Coefficient \\
of the social \\
dimension
\end{tabular} & 0.821 & $\begin{array}{l}\text { Coefficient } \\
\text { of the } \\
\text { economic } \\
\text { dimension }\end{array}$ & 0.871 \\
\hline
\end{tabular}

Table (2) shows that all dimensions relate to each other and also link with the whole degree of the measurement, with a statistically significant correlation at a significant level (0.05-0.01). This confirms certainty for the construct validity.

Measurement of scale reliability: The researcher calculates the reliability through applying the scale on a sample consisting of (15) divorced women twice, with a time interval of 15 days between the first test and the second one. The results of reliability on the scale as a whole, and its dimensions using the Spearman test $(\mathrm{t})=(0.91)$, mean that the scale has a high degree of reliability.

Alpha Cronbach's test was used to calculate the weights of the scale phrases in order to obtain the value of the alpha coefficient for each dimension of the scale and the dimensions of the scale as a whole. The following table illustrates this:

Table (3) Alpha Cronbach's coefficients for each dimension of the scale and for the scale as a whole

\begin{tabular}{|c||c|c|}
\hline \hline Dimensions & Number of Items & Alpha Cronbach \\
\hline \hline Psychological Stressors & 15 & 0.876 \\
\hline \hline Social Stressors & 15 & 0.926 \\
\hline \hline Economic Stressors & 14 & 0.919 \\
\hline \hline Scale as Whole & 44 & 0.92 \\
\hline
\end{tabular}


As we can see, the scale has a high degree of the reliability (0.92).

\section{Statistical analysis:}

- A (T) test was used in order to find the differences between pre and post measurement, and the degree of those differences.

- the researcher used the statistical software package SPSS / PCV.24 in tabulating and calculating the study data and the correlations between it.

\section{Results:}

\section{(1) Testing the first sub-hypothesis of the study:}

Table (4) The significance of differences between pre and post measurement of psychological stressors faced by divorced women

\begin{tabular}{|c|c|c|c|c|c|c|c|c|}
\hline \multicolumn{2}{|c|}{$\begin{array}{c}\text { Before } \\
\text { Intervention }\end{array}$} & \multicolumn{2}{|c|}{$\begin{array}{c}\text { After } \\
\text { Intervention }\end{array}$} & \multirow[t]{2}{*}{$\mathrm{df}$} & \multirow{2}{*}{$\begin{array}{c}\text { eta } \\
\text { squared }\end{array}$} & \multirow{2}{*}{$\underset{\text { (Calculated) }}{\mathrm{T}}$} & \multicolumn{2}{|c|}{$\begin{array}{c}\mathrm{T} \\
(\mathrm{Tabl}) \\
\end{array}$} \\
\hline$\overline{\bar{x}}$ & S.D & $\overline{\bar{x}}$ & "S.D & & & & 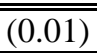 & $(0.05)$ \\
\hline 2.37 & 0.31 & 1.33 & 0.17 & 26 & 0.917 & 17.001 & 2.06 & 1.71 \\
\hline
\end{tabular}

Table (4) indicates that there are statistically significant differences between the average of the pre-test and post-test for the experimental group after using the life model to alleviate the psychological stressors of divorced women, in favor of the post-test. The arithmetic mean for the pre-test was $=(2.37)$ with a standard deviation of $=(0.31)$, while it became $(1.33)$ with a standard deviation of $=(0.17)$ after the professional intervention.

To determine the effectiveness of the professional intervention program, in enabling the goal system (divorced women) to alleviate psychological stressors after implementing the program, the researcher calculated the effect factor (ETA 2) which reached $=(0.917)$. This indicates the positive effect of the professional intervention program contents: roles, strategies, techniques and professional means which were used to alleviate psychological stressors for divorced women.

In light of the above, it is clear that the first sub-hypothesis of the study is valid. These differences are due to the contents of the professional intervention program that include practice of roles and strategies, reliance on various professional techniques, as well as knowledge of how to alleviate psychological stressors and overcome their negative effects on divorced women. 


\section{(2) Testing the second sub-hypothesis of the study:}

Table (5) The significance of differences between pre and post measurement of sociological stressors faced by divorced women

\begin{tabular}{|c|c|c|c|c|c|c|c|c|}
\hline \multicolumn{2}{|c|}{$\begin{array}{c}\text { Before } \\
\text { Intervention }\end{array}$} & \multicolumn{2}{|c|}{$\begin{array}{c}\text { After } \\
\text { Intervention }\end{array}$} & \multirow[t]{2}{*}{ df } & \multirow{2}{*}{$\begin{array}{c}\text { eta } \\
\text { squared }\end{array}$} & \multirow{2}{*}{$\begin{array}{c}\mathrm{T} \\
\text { (Calculated) }\end{array}$} & \multicolumn{2}{|c|}{$\begin{array}{c}\mathrm{T} \\
(\mathrm{Tabl})\end{array}$} \\
\hline$\overline{\mathrm{x}}$ & S.D & $\overline{\bar{x}}$ & S.D & & & & 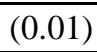 & $\begin{array}{c}(0.05) \\
\end{array}$ \\
\hline 2.42 & 0.26 & 1.32 & 0.18 & 26 & 0.950 & 22.273 & 2.06 & 1.71 \\
\hline
\end{tabular}

Table (5) shows that there are statistically significant differences between the average of the pre-test and post-test for the experimental group when using the life model in alleviating the social stressors of divorced women, in favor of post-test. The arithmetic mean of the pre-test was $=(2.42)$ with a standard deviation of $=$ $(0.26)$, while it became $=(1.32)$ with a standard deviation of $=(0.18)$ after the professional intervention.

To determine the effectiveness of the professional intervention program in enabling the goal system (divorced women) to alleviate social stressors after the application and the magnitude of its impact, the researcher calculated the effect factor (ETA 2) which reached = (0.950). This indicates the positive effect of the professional intervention program contents: roles, strategies, techniques and professional means which were used to alleviate social stressors for divorced women.

In light of the above, it is clear that the second sub-hypothesis of the study is valid. These differences are due to the contents of the professional intervention program, which include: practice of roles and strategies, relying on the various professional techniques, as well as knowledge of how to alleviate social stressors and overcome their negative effects on divorced women.

\section{(3) Testing the third sub-hypothesis of the study:}

Table (6) The significance of differences between pre and post measurement of economic stressors faced by divorced women

\begin{tabular}{|c|c|c|c|c|c|c|c|c|}
\hline \multicolumn{2}{|c|}{$\begin{array}{c}\text { Before } \\
\text { Intervention }\end{array}$} & \multicolumn{2}{|c|}{$\begin{array}{c}\text { After } \\
\text { Intervention }\end{array}$} & \multirow[t]{2}{*}{ df } & \multirow{2}{*}{$\begin{array}{c}\text { eta } \\
\text { squared }\end{array}$} & \multirow{2}{*}{$\begin{array}{c}\mathrm{T} \\
\text { (Calculated) }\end{array}$} & \multicolumn{2}{|c|}{$\begin{array}{c}\mathrm{T} \\
\text { (Tabl) }\end{array}$} \\
\hline 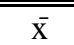 & 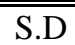 & 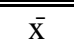 & 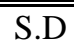 & & & & (0.01) & "ב(0.05) \\
\hline 2.31 & 0.38 & 1.58 & 0.27 & 26 & 0.895 & 14.892 & 2.06 & $\begin{array}{l}1.71 \\
\end{array}$ \\
\hline
\end{tabular}

Table (6) shows that there are statistically significant differences between the average of the pre-test and post-test for the 
experimental group after using the life model to alleviate economic stressors for divorced women, in favor of post-test. The arithmetic mean of pre-test was $=(2.31)$ with a standard deviation of $=(0.38)$, which became $=(1.58)$, with a standard deviation of $=(0.27)$ after the professional intervention.

To determine the effectiveness of the program of the professional intervention in enabling the goal system (divorced women) to alleviate economic stressors after the application of its impact, the researcher calculated the effect factor (ETA 2) which reached $=(0.895)$, which indicates the positive effect of the professional intervention program contents: roles, strategies, techniques and professional means which were used to alleviate economic pressures for divorced women.

In light of the above, it is clear that the third sub-hypothesis of the study is valid. These differences are due to the contents of the professional intervention program, which include: practice of roles and strategies, relying on various professional techniques, as well as knowledge of how to alleviate economic stressors and overcome their negative effects on divorced women.

\section{(4) Testing the main hypothesis of the study:}

Table (7) The significance of differences between pre and post measurement of life stressors facing divorced women

\begin{tabular}{|c|c|c|c|c|c|c|c|c|}
\hline \multicolumn{2}{|c|}{$\begin{array}{c}\text { Before } \\
\text { Intervention }\end{array}$} & \multicolumn{2}{|c|}{$\begin{array}{c}\text { After } \\
\text { Intervention } \\
\end{array}$} & \multirow[t]{2}{*}{ df } & \multirow{2}{*}{$\begin{array}{c}\text { eta } \\
\text { squared }\end{array}$} & \multirow{2}{*}{$\begin{array}{c}\mathrm{T} \\
\text { (Calculated) }\end{array}$} & \multicolumn{2}{|c|}{$\begin{array}{c}\mathrm{T} \\
(\mathrm{Tabl}) \\
\end{array}$} \\
\hline$\overline{\mathrm{x}}$ & S.D & $\overline{\mathrm{x}}$ & S.D & & & & $(0.01)$ & $(0.05)$ \\
\hline 2.37 & 0.30 & 1.40 & 0.18 & 26 & 0.909 & 16.145 & 2.06 & 1.71 \\
\hline
\end{tabular}

Table (7) shows that there are statistically significant differences between the average of the pre-test and post-test for the experimental group after using the life model to alleviate life stressors for the divorced women, in favor of the post-test. The arithmetic mean of the pre-test was $=(2.37)$ with a standard deviation of $=(0.30)$, which became $=(1.40)$, with a standard deviation of $=(0.18)$ after the professional intervention.

To determine the effectiveness of the professional intervention program in enabling the goal system (divorced women ) to alleviate life stressors after application and the magnitude of its impact, the researcher calculated the effect factor (ETA 2) which reached = (0.909). This indicates the positive effect of the professional 
intervention program contents: roles, strategies, techniques and professional means which were used to alleviate life stressors for divorced women.

In the light of the above, it is clear that the main hypothesis of the study is valid. These differences are due to the contents of the professional intervention program, which include: practice of roles and strategies, relying on various professional techniques, as well as knowledge of how to alleviate life stressors and overcome their negative effects on divorced women.

\section{Discussion:}

The study found that there are statistically significant differences in degrees in the post-test on the scale of alleviating life stressors for divorced women, between the control group and the experimental group, in favor of the experimental group.

The study tried to verify how a social work intervention program, built on a life model, can help to alleviate the stressors that divorced women face. Divorce in Egypt is a big, complex and sensitive problem, the social work profession must do something to confront this problem. Women and children are more often affected by the negative impact of this problem than any other members of the family.

The results indicate that the severity of the consequences of divorce varies according to the psychological, social, and economic stressors that affect the lives of divorced women. Additionally, the results agree with Jirjis H. \& Ayman A. (2015) in their study which found that divorced women in our country struggle to find social acceptance and social adjustment in society (p.1). This study indicates that there are many life stressors facing divorced women, and that divorce has a negative effect on women, causing economic, psychological and social problems.

This agrees with Abdel Hamid M. (2013) who indicated that women face many psychological stressors after divorce, experiencing emotional disorders such as regret and remorse, emotional vacuum, lack of confidence, and depression. The majority of participants expressed that they felt constant worry about their personal future, and had a pessimistic outlook regarding their family.

Also divorced women stated that they felt depression when facing difficult life situations, and emotional vacuum. Both 
demonstrate a high rate of responses, followed by lack of confidence. This agrees with Abd Allah E.H. (2012) whose study results indicated that divorced women suffer from depression, anxiety and problems associated with self-esteem, regret and remorse.

Results indicated that divorced women suffer from all these negative feelings associated with divorce because, as the majority of them stated, they see their life as having broken down after divorce from their husband, and experience feelings of guilt about the situation for their children after divorce. This is consistent with what Rahman, Giedraitis, \& Akhtar, (2013) referred to in his study indicating that women are the primary victims who carry most of the instantaneous consequences of divorce and ultimately pay most of the costs of its adverse effects (p.26).

The results of this study found that divorced women felt psychological stressors imposed by their family were enough to create feelings of regret and remorse, and indicated that the majority of divorced women cannot endure the direct criticism from their family. Also divorced women suffered from a lack of confidence as a consequence of divorce, stating that their actions tended to cause mental strain. Divorced women would also assume responsibilities that caused multiple psychological stressors, including feelings of loneliness and insecurity.

So, Trivedi J.K. \& Sareen H. (2009) indicates that divorced women suffer from varying psychological stressors, such stressors could be harbingers of psychiatric illnesses (e.g., depression, anxiety, substance dependence), and hence should be taken into account by treating physicians, social workers and others who come to the aid of such women. (p.37)

This study's results found that divorced women face social stressors related to the situation within the family, affect her social roles, functions and relations with her friends, neighbors and relatives. Divorced women are even reluctant to discuss their situation with relatives, they reported that they avoid attending family events for fear of the negative perception, so women who go through divorce are usually shunned by their own family members. The results also indicate that friends and peers sometimes treat divorced women as failures, they stated that they felt ashamed to see anguish towards them in the eyes of others. The study showed that divorced women 
also suffered from a weakening of relationships with their female friends after divorce.

This agrees with Parvez K.N (2011) who noted that women are faced by social exclusion and stigma, harassment in the work place, difficulties in a second marriage, downswing changes in lifestyle in the face of social expectations, and psychological and physiological disturbance in post-divorce situations. (P.ii) Divorce also effects children and their relationship with their parents, children struggle to maintain a balanced social interaction with both parents after divorce (Aly A. 2007).

The results of this study found that divorced women tended to suffer from economic stressors such as considerable financial losses, especially those who have children. Economic stressors included lack of a stable income, a lack of housing, a lack of employment, and unpaid alimony from former husbands. The majority of participants reported that their current income was not enough for the necessary requirements of life. So the lack of a stable income after divorce is an obstacle for women.

The majority of comments consistently referred to the reduction of income after divorce, with commitments to pay alimony and long periods of litigation increasing economic stressors. Economic stressors also had a significant impact on the children of divorced parents, with the majority of participants stating that they find it difficult to provide health care for their family, and are choosing to remove their children from education, forcing them to work to help the family, not knowing of any alternative ways to develop household income under the current circumstances. This is consistent with Mostafa M. (2003) whose study results found that most divorced mothers move back to their parents' homes and rely on extended family support. Although divorced women and their children benefit from such support to reduce emotional stress, such a move compromises the women's sense of independence, especially concerning their finances. Children experience other forms of pressure once they move to their grandparents' home, which is represented in the reduction in the quality and quantity of interaction with their 
fathers. They were found to be vulnerable to various forms of emotional pressures, such as fear, sadness, and worry.

So, divorce has become a key life-course risk that can have significant economic impacts. Overall, the analyses show that the economic consequences of divorce are still more negative for women than for men after the turn of the millennium. This analysis agrees with Brockel M. \& Andreb H.J (2015) who indicated that female labor participation has increased and the public child care system has expanded (p.277).

\section{Recommendations:}

The study recommends that the generalist practice of social work should invest in ways to protect families from the occurrence of divorce. If divorce does occur, social work should strengthen divorced women's personalities to improve their social relation network with the surrounding environment, and to take advantage of all sources of support. Also, to help her to achieve consistency and balance and the development of her capabilities to cope with the divorce stressors. The generalist practice of social work must be concerned with experimenting the life model with clients in other circumstances and other types of problems, so as to use the flexibility and multiplicity of using therapeutic methods through the professional intervention of social work.

The researcher ensures that the successful use of the life model depends largely on the degree of cooperation and participation of the clients, team work and organization. This study recommends more future research into divorced women and the impact of divorce on children and society. So, we need more professional and academic studies on the causes and consequences of divorce in Egypt. It would be appropriate for organizations to develop programs dealing with the harmful impact of divorce on the family as a whole, and particularly on women and children.

Doing more research and studies are important to understanding why divorce rates are increasing in Egypt. This will help social work practice to develop relevant intervention programs.

\section{Reference}

Abd Allah, E. H. (2012). The Effect of divorce and emotional separation on female psychological disorder (comparative study), phd, psychology department, faculty of arts, Fayoum University, Egypt, Retrieved from http:// 
srv4.eulc.edu.eg/eulc_v5/Libraries/

Thesis/BrowseThesisPages.aspx?fn...BibID

Abdel Hamid, M. (2013). Logo therapy practice in case work to reduce damages caused by divorce in the early stage of marriage: applied study on girls in slum areas, $26^{\text {th }}$ international scientific conference for social work, social work and slum development, march, part (6), faculty of social work, Helwan university, Cairo, Egypt, pp:228-2400.

Aly, E. (2007). A Study of social relation problems among children under court parental visitation, unpublished Master's thesis, faculty of social work, Helwan University, Helwan, Egypt.

Amato, P. R. \& James, S. (2010). Divorce in Europe and the United States: commonalities and differences across nations, family science,1(1), 2-13. Doi:10.1080119424620903381583.

Amato, P. R. (2000) The consequences of divorce for adults and children. Journal of marriage and the family, 62(6): 1269-1287.

Amato, P. R. (2010). Research on divorce: continuing developments and new trends, journal of marriage and family,72(3): 65066.doi:101111/j.1741.2010.00723.x.

Amato, P.R. \& Keith, B. 1991. Parental divorce and the well-being of children: a meta-analysis. Psychological Bulletin, 110 (1), 26-46.

Austen, S. (2004). Labor supply and the risk of divorce: An analysis of Australian data. The Australian economic review, 37,153165.doi:10:1111/j.1467-8462.2004.00316.x

Brockel, M. \& Andreb, H. J (2015). The economic consequences of divorce in Germany: what has changed since the turn of the millennium?, comparative population studies, federal institute of population research, 40 (3), 277:312 .doi.org/10.12765/CPoS-2015-04en.

Callens, M. \& Croux, C. (2009). Poverty dynamics in Europe: a multilevel recurrent discrete-time hazard analysis. International sociology 24(3): 368396. DOI: $10.1177 / 0268580909102913$

DiPrete, T. A. \& McManus, P. A. (2000). Family change, employment transitions, and the welfare state: household income dynamics in the United States and Germany. American sociological review 65(3): 343-370.

Garriga, A. \&Härkönen, J. (2009). The effects of marital instability on children's well-being and intergenerational relations. EQUALSOC State-ofthe-art report. universidad Pompeu Fabra and Stockholm University.

Germain, C. B., \& Gitterman, A. (1996). The life model of social work practice: Advances in theory and practice ( $2 \mathrm{~d}$ ed.). New York: Columbia University Press.

Gholami, A. \& Bashlide, K. (2014). Effect of emotional intelligence on general health of divorced women, Quarterly journal of social work, 3 (4), 28-39. 
Gitterman, A. \& Shulman, L. (2005). Mutual aid groups, vulnerable populations, and the life cycle, third edition, Columbia University press, New York, p.26.

Hughes, M.E.\& Waite, L. J. (2009). Marital biography and health at midlife, journal of health and social behavior, 50, (3),pp:344-358.

Jirjis, H. \& Ahmed, A. (2015). Social adjustment of divorced women in Egyptian society, field study in Gharbia Governorate, Researcher in sociology sociologist, pp:1-44. Retrieved from http://www.swmsa.net/art/s/2401/.

Kelly, J.B., \& Emery, R.E. (2003). Children's adjustment following divorce: Risk and resilience perspectives, family relations, 52, 352-362.

KÜÇÜKŞEN, K. (2016). Being a divorced woman in a patriarchal society: example of Konya", journal of international social research, Jun, 9 (44), 826833.

Margit, G. (2010). Psychosocial and legal Perspective of marital breakdown : with special emphasis on Spain .springer-verlag Berlin Heidelberg, New York .

Mostafa, M. (2003). Awareness of the effect of divorce on children: an exploratory study in UAE', paper presented at the 16th social work conference, faculty of social work, Helwan university, Helwan, Egypt, 14-16 March.

Nida, Z. \& rukhasana, K. (2014 ). Emotional and social problem in divorced and married women", journal of social sciences, 8 (1), 31-35.

Parvez, K. N. (2011). Social changes and woman -initiated divorce in Dhaka, Bangladesh: Gaining or losing power? Master of philosophy in gender and development, department of health promotion and development, faculty of psychology, universities Bergensis, Norwegian.

Pirmoradi, M. R., Poya, F. S., Rad, M. T., Veisy, F.,Gheitarani, B., Davoodi, R. \& Ghahari, S. (2016). Comparison of anxiety, depression and stress and emotional self-regulation in normal and divorced women, international journal of Tropical Medicine,11(5), 159-164. Doi:10.3923/ijtmed.

Rahman, M. M., Giedraitis, V. R., \& Akhtar, T. (2013). The social sanction of divorce: who ultimately pays the social costs of its adverse effects? Sociology and anthropology, 1(1), 26-33, DOI:10.13189/sa.2013.010103

Smock, P.J., Manning, W. D. \& Gupta, S. (1999). The effect of marriage and divorce on women's economic well-being, American sociological review,64, (6), 794:812.

Smyth, B.M. (2004). Post separation fathering: what does Australian research tell us? Journal of family studies,10, (1), 20-49. http://dx.doi.org/10.5172/jfs.327.10.1.20

Tennant, C. (2002). Life events, stress and depression: A review of recent findings. Australian and New Zealand journal of psychiatry, 36, 173-182. 
Trivedi J. K., Sareen H. \& Dhyani M. (2009). Psychological aspects of widowhood and divorce, Mens Sana Momogr, (7), (1),pp:37-49. doi: $\underline{10.4103 / 0973-1229.40648}$

Urie, B. (1986). Ecology of the family as a context for human development: Research perspectives, developmental psychology, 22 (6), 723-742. http://dx.doi.org/10.1037/0012-1649.22.6.723.

Uunk, W. 2004. The economic consequences of divorce for women in the European Union: the impact of welfare state arrangements, European journal of population, 20, (3), pp: 251-285. doi:10.1007/s10680-004-1694-0.

Wikipedia Divorce, (2008). Retrieved from http://en.wikipedia.org/wiki/Divorce

Yang, L. L. (2008). The life stories of motherhood among divorced women in Taiwan, journal of nursing research, 16(3), 220-230. Doi:10.1097/0/.jnr.0000387309.19493.bo. 